\title{
Prediction of regional coronary perfusion abnormalities using regional two-dimensional strain in non-ST elevation acute coronary syndrome
}

\section{Daniel Lovrić*, \\ Marijan Pašalić, Vlatka Rešković Lukšić, \\ Kristina Gašparović, Dejan Došen, \\ Jana Ljubas Maček, Zvonimir Ostojić, \\ Marija Brestovac, Davor Miličić, Jadranka Šeparović Hanževački}

University of Zagreb School of Medicine, University Hospital Centre Zagreb, Zagreb,

Croatia
RECEIVED:

September 24, 2017

ACCEPTED:

September 26, 2017

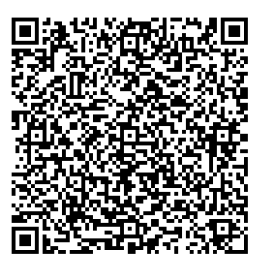

KEYWORDS: regional wall motion assessment, acute coronary syndrome, coronary stenosis localization, regional 2D strain

CITATION: Cardiol Croat. 2017;12(9-10):349-350. / https://doi.org/10.15836/ccar2017.349

*ADDRESS FOR CORRESPONDENCE: Daniel Lovrić, Klinički bolnički centar Zagreb, Kišpatićeva 12, HR-10000 Zagreb, Croatia. / Phone: +385-91-44-88-350 / E-mail: daniel@dlovric.net

ORCID: Daniel Lovrić http://orcid.org/0000-0002-5052-6559 • Marijan Pašalić http://orcid.org/0000-0002-3197-2190 Vlatka Rešković Lukšić http://orcid.org/0000-0002-4721-3236 • Kristina Gašparović http://orcid.org/0000-0002-1191-4831 Dejan Došen http://orcid.org/0000-0002-2641-4768 • Jana Ljubas Maček http://orcid.org/0000-0001-7171-2206 Zvonimir Ostojić http://orcid.org/0000-0003-1762-9270 • Marija Brestovac http://orcid.org/0000-0003-1542-2890 Davor Miličić http://orcid.org/0000-0001-9101-1570 • Jadranka Šeparović Hanževački http://orcid.org/0000-0002-3437-6407

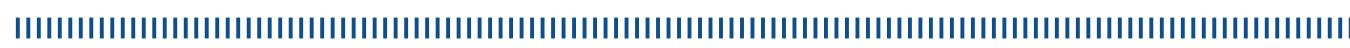

Background: Visual assessment of regional wall motion abnormalities (RWMA) on echocardiography represents the current standard in assessing the coronary artery disease (CAD) induced changes in myocardial contractility. Although it has been proven to predict long-term outcomes it's hard to rely on in acute situations due to the patient dependent variance in image acquisition quality and interoperator variability. It has been shown that 2D strain (2DS) is a sensitive indicator for sub-clinical myocardial injury. ${ }^{1,2}$ The purpose of this study was to assess the value of regional 2DS performed early in patients with non-ST elevation acute coronary syndrome (NSTE-ACS) for predicting localization of ischemia-inducing stenosis and compare it with RWMA.

Patients and Methods: We performed a retrospective analysis of patients admitted from January 2013 till December 2015 with the diagnosis of NSTE-ACS. Exclusion criteria were no coronary angiography, known prior CAD, no echo in 24 hours prior to angiography and image quality not adequate for 2DS analysis. Total of 123 patients were included. 4 clinicians blinded to laboratory and ECG results performed 2DS analysis of regional longitudinal peak systolic strain (LPSS) according to the 18-segment model, and RWMA were categorized according to the wall motion score guidelines, as interpreted by the clinician performing the original echo.

Results: We found significant correlation of flow limiting stenosis, defined as a narrowing of $>70 \%$ on angiography, with LPSS decrease for all three coronary vessels (Table 1). RWMA shows good predictive power of stenosis in LAD and LCX, but not in RCA (Figure 1). However, LPSS was more precise overall (mean sensitivity $75.6 \%$ vs $39.5 \%$,
TABLE 1. Regional visual wall motion assessment 2D longitudinal peak systolic strain values according to segments and location of coronary stenosis.

\begin{tabular}{llc} 
Segment & Lession location & $\boldsymbol{P}$ \\
\hline APLAX Basal anteroseptum & LAD & 0.098 \\
\hline APLAX Mid anteroseptum & LAD & $<0.0001$ \\
\hline APLAX Apical anteroseptum & LAD & $<0.0001$ \\
\hline APLAX Apical inferolateral & LCX & $<0.0001$ \\
\hline APLAX Mid inferolateral & LCX & 0.04 \\
\hline APLAX Basal inferolateral & LCX & 0.01 \\
\hline A4C Basal inferoseptal & RCA & 0.087 \\
\hline A4C Mid inferoseptal & LAD & 0.1 \\
\hline A4C Apical inferoseptal & LAD & $<0.0001$ \\
\hline A4C Apical anterolateral & LAD & 0.003 \\
\hline A4C Mid anterolateral & LCX & 0.366 \\
\hline A4C Basal anterolateral & LCX & 0.015 \\
\hline A2C Basal inferior & RCA & 0.133 \\
\hline A2C Mid inferior & RCA & 0.722 \\
\hline A2C Apical inferior & LAD & 0.15 \\
\hline A2C Apical anterior & LAD & $<0.0001$ \\
\hline A2C Mid anterior & LAD & 0.027 \\
\hline A2C Basal anterior & LAD & 0.032 \\
\hline \hline AD & & \\
\hline
\end{tabular}

$\mathrm{LAD}=$ left anterior descending coronary artery; $\mathrm{LCX}=$ left circumflex

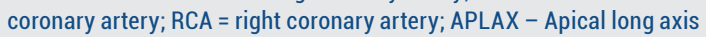
view; $A 4 C$ - Apical four chamber view; $A 2 C$ - Apical two chamber view. 

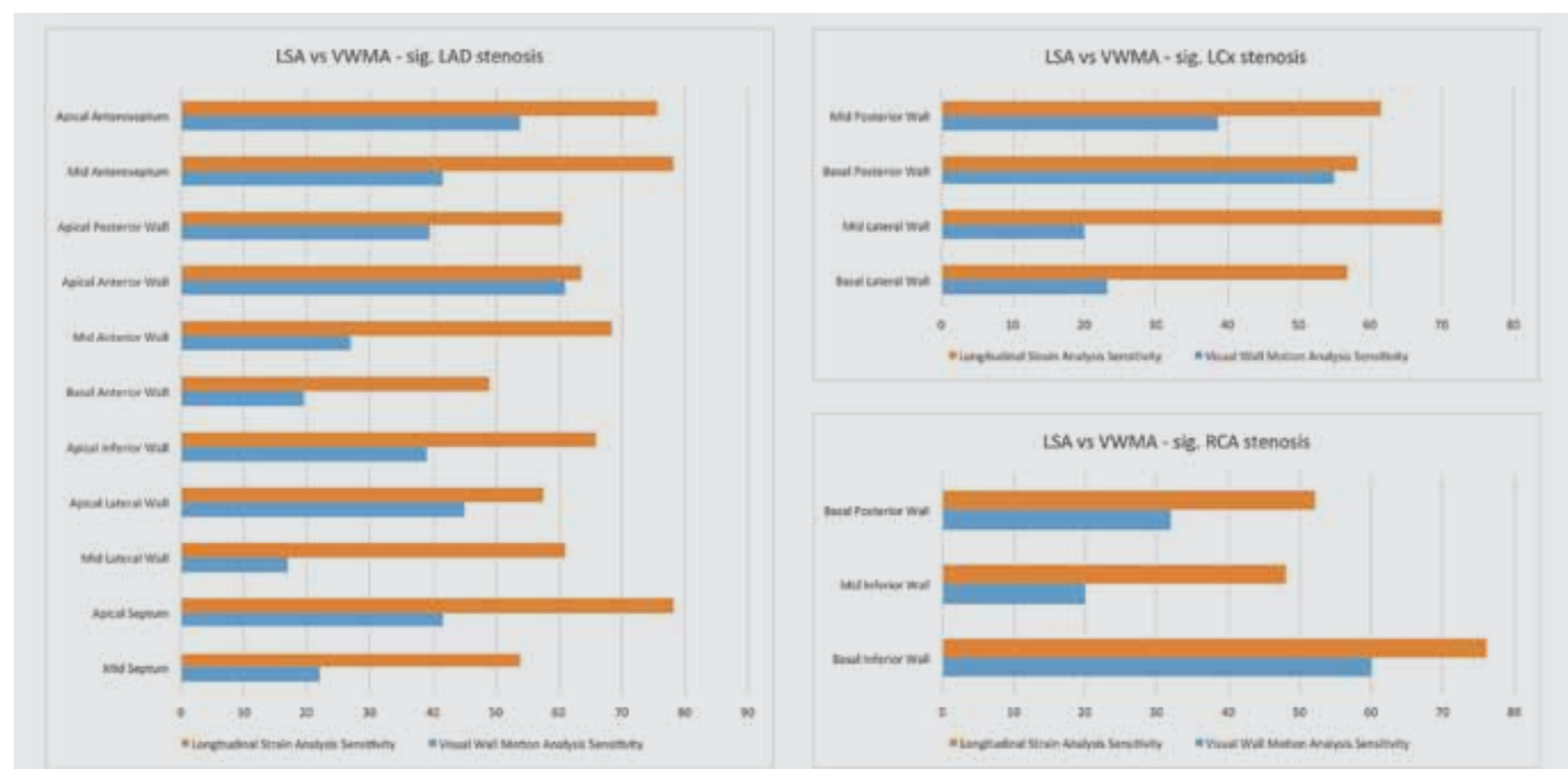

FIGURE 1. Comparison of sensitivity for detection of significant coronary artery stenosis of regional visual wall motion assessment (VWMA) vs 2D longitudinal peak systolic strain analysis (LSA).

$\mathrm{P}<0.001$ ), and significant difference was present even after accounting for potentially confounding factors like arterial hypertension, smoking, alcohol, atrial fibrillation, valvular disease, age or prior medical therapy.

Conclusion: We have shown that there is significant correlation between a decrease in LPSS and localization of significant stenosis in patients with NSTE-ACS, and that it is significantly more accurate in detecting ischemia induced loss of myocardial contractility than the visual assessment of RWMA.

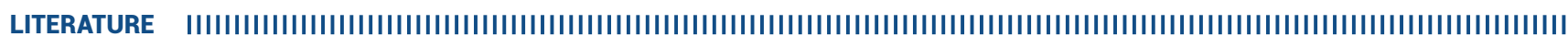

1. Sabia P, Afrookteh A, Touchstone DA, Keller MW, Esquivel L, Kaul S. Value of regional wall motion abnormality in the emergency room diagnosis of acute myocardial infarction. A prospective study using two-dimensional echocardiography. Circulation. 1991 Sep;84(3 Suppl):185-92. PubMed: https://www.ncbi.nlm.nih.gov/pubmed/1884510

2. Montgomery DE, Puthumana JJ, Fox JM, Ogunyankin KO. Global longitudinal strain aids the detection of non-obstructive coronary artery disease in the resting echocardiogram. Eur Heart J Cardiovasc Imaging. 2012 Jul;13(7):579-87. https://doi.org/10.1093/ejechocard/jer282

3. Choi JO, Cho SW, Song YB, Cho SJ, Song BG, Lee SC, et al. Longitudinal 2D strain at rest predicts the presence of left main and three vessel coronary artery disease in patients without regional wall motion abnormality. Eur J Echocardiogr. 2009 Jul;10(5):695-701.

https://doi.org/10.1093/ejechocard/jep041 